\title{
Developing Motorsports Talents towards Achieving a Successful and Sustainable Business Ventures Framework upon the Completion of an Active Motorsports Career
}

\author{
Syarizal Abdul Rahim, Norailis Ab. Wahab, and Razli Che Razak
}

\begin{abstract}
In today's business environment, talent has become the potentially powerful source of competitive advantage. It is the fundamental building block to creating an organization which is capable of learning, innovating and changing, as well as executing new processes. It has been said that, talent management include the additional management processes and opportunities put in place for people in the organization that are considered to be talented. This paper intends to present a guide for racers to drive their companies by extending their success on the race tracks into business. This piece of work is based on the information gathered through in-depth interviews with three business owners that are also active racers. In the course of the interview, feedbacks regarding benchmarking through talent in motorsports and businesses were sought. The importance of talent management as seen through the prism of how top performers in motorsports have succeeded in driving their business while still producing impressive results on the race tracks was established in this study.
\end{abstract}

Index Terms-Benchmarking, business, motorsports, talents.

\section{INTRODUCTION}

The future of motorsports particularly in two wheels championships is developing at a steady rate that provides rooms for improvement especially through research and development. This sport is a reflection of the Malaysian youth development policy which serves as a platform to nurture talent, skill and professionalism. In motorsports, winning is the absolute aim for every racer who are diverse in age and talent. The following are the young talents in current motorsports arena representing Malaysia at international events: Hafizh Syahrin Abdullah (19 years old) participates in Moto2 World Championship; Azlan Shah Kamaruzaman (29) in MFJ Superbike All Japan Road Race Championship; Mohamad Zamri Baba (29) in Asia Road Race Championship, Mohd Emir Firdaus Hasan (26) in Suzuka 8-hour Endurance Road Race and Mohd. Habibullah Mohd. Salleh (21) in FIM Supermoto World Championship. These racers contribute to the phenomenon inside tracks. Just like other sports, motorsport is now a huge industry comprising other non-sport sectors such as technical/engineering, event management, marketing, broadcasting, insurance, merchandise, tourism as well as food and beverages.

Manuscript received March 12, 2014; revised June 5, 2014.

Syarizal Abdul Rahim is with the Universiti Malaysia Kelantan, Malaysia (e-mail: syarizal.ar@umk.edu.my).

\section{LITERATURE REVIEW}

This section presents the background of benchmarking and talent from relevant previous studies. It should assist readers to develop an understanding of benchmarking and talent with respect to sports and business.

\section{A. Benchmarking in Business}

Benchmarking is accepted worldwide as a tool of continuous improvement [1]-[3] highlighted the importance of understanding "benchmarking" and its effects on a business. Even as [4] comprehends function of benchmarking guarantees that knowledge is gained across areas. Then again, application of the tool in managing processes ensures the sustainability of an organization in the business arena [5].

It is necessary to benchmark global industry standards including a look into the best practices at the team, workgroup, and organizational level [6], [7]. More so, [8] constructed case studies that draw attention to the importance of holistic approach to organizational comparison instead of focusing on particular parts in an organization. Furthermore, [9] highlighted that respective organizations should put emphasis on different approaches to benchmarking depending upon regulatory context and company strategy.

Ref. [10] mentioned the areas with the widest discrepancies in maturity of practices that are closely related to talents include human resource development and management, quality and operational results as well as customer focus and satisfaction. In fact, [11] stressed on the need to increase awareness of the importance of human resource in organizations. In addition, the role of human resource was the most influential factor on benchmarking adoption, followed by top management commitment [12]. There is high level of influence of management in managing people with unique knowledge and skills [13].

\section{B. Talents in Business and Sports}

There is no single or universal contemporary definition of "talent" in any one language. Likewise, there are different organizational perspectives on talent [13]. According to [14] the role of talent has been widely acknowledged and renewed significance has been attached to the management of talent. On top of that, a study by [15] found that different perspectives of talents were often present in varying degrees even within the same organization. Thus, talent is critical due to its role in catalyzing the pursuit of excellence which is the commitment to do and be the best all aimed towards personal growth and attainment of individual maximum 
potential [16], [17].

Ref. [18] agreed that talent is not just about having the brainpower, the knowledge, the experience, the skill or the mental and physical characteristics to do something correctly, it is also about the ability to do something different or at a higher order of difficulty and complexity in the future. [19] opined that in order to develop strategic capability, potential employers of choice need to ensure they clarify the requirements for their talent program including the success criteria to be used to measure their program's contribution. In addition, these measurements should be able to stand up to comparisons in the industry and with the best practice of other organizations [20].

There are needs for future research within the broad topics of talent management to enable investigation of concepts that cut across multiple functions and organizations within a supply chain [21]. This review not only shows us the link that exists between these two mediums but it also indicate that the link is a healthy one [22]. The research found that there are areas in which business leaders can learn lessons from sport, especially in terms of change and staff development [23]. From the literature that is available, and reviewed to date, many organizations are currently using the style and methods of coaching an athlete, and are utilizing similar tactics that occur in the sport in their own company's operational management style [24].

Businesses largely compete on the basis of available talent, competency and capability [25]. The business needs are derived from the business model and competitive issues such as business strategy, growth, innovation, customers, costs, international, people and diversification [26]. In fact, [27] also suggested that employers are fighting to get talented workers and get connected [28] in order to maintain a prosperous business because there are needs of field expertise in an organization [29].

On the other hand, [30] argued that different skills are needed for sports and business as well as applying different strategies aimed at improving their competitive positions. Even to obtain a consistent performance from employees and players would be quite an accomplishment at certain times [31], [32] proposed the fifth pillar that stressed on important aspect of athletic career support and post career.

Realizing the importance of motorsports to the nation, it is best if it has a structured talent development program that encompasses selection till post career paths. Therefore, the authors aimed to achieve these objectives through this paper by: i) comparing the theories and the practices of talent management in motorsports; and ii) exploring the relationship of talent management and businesses in Malaysia.

\section{Methodology}

The information was gathered through in-depth interviews with three business owners who are also active racers. It is a suitable research technique for relatively unexplored subject [33]. It was decided to use in-depth interviewing as the main method to collect data for the study since an interpretative approach was adopted for the investigation. The authors required different types of information that qualitative studies can provide which is rich in detail.

The profile of the respondents shows that their average duration of being racers is fifteen years. The purposive sampling as mentioned by [34] has two principal aims. The first is to ensure that all the key components that are relevant to the subject matter are covered. While the second is to ensure that within each of the key criteria, some diversity is included so that the impact of the characteristic concerned can be explored. Members of this sample are chosen with a purpose to represent racers that are managing their own motorsports-related businesses. Interviews were conducted at their own premises. The interviews lasted for an average of one hour. A recorder was used to facilitate the interviews as well as comprehensive notes of the answers. The results of each interview were transcribed immediately after each session.

The interview sessions were divided into two main sections: first section was on the interviewees' demographic profile since their involvement in races until they opened their own businesses. This part asked for background information, which includes type of ownership, age of business, experiences to manage business, number of employees and education background. Later section concerned the generic motorsports and business related activities. Initially, to crystallize the responses, further analysis using NVivo software mainly involved the data from latter section collected with the aim of identifying and classifying feedbacks regarding talent supply chain in motorsports and business.

\section{FINDINGS AND DISCUSSION}

The results of interviews and its discussion will be elaborated by points taken from the interviewees' statements that are related to their talent in motorsports and their involvement in business. It began with their responses on the understanding the preparation before they started up their business. The next points are on their choices in post racer career; the impacts on their businesses and involvement in races nowadays.

\section{A. Career Path}

"The racer's direction in Malaysia is still unclear because that of European countries is much more ahead and still evolving. Therefore, those who have the talent will have bright future in the sports. We should do the same thing by focusing on grooming these young talents."-Interviewee 3 .

From the above response, the interviewee recommended period for racer's career start up and ending. He stressed that as the start up; a racer should be on board in pocket bike competitions as early as five years old to be on tracks. Early age exposure promised an elongated way for them in creates their success from one level to another swiftly. "We" as in the statement referring to the authorities such as Ministry of Youth and sports as well as the others that have the intentions to manage race events consistently in a calendar year. They should be able to take actions with the unclear guidelines and unclear path to assist these young talents to step ahead in this motorsports. 


\section{B. Individual Vision, Passion and Qualities}

"I own this workshop since 2007. Prepare my own bike and for...involve in races with the company's name.Interviewee 2.

"As for me, it depends on the particular individual. Everyone should be determine and be consistent in work. Never be lazy. If these attitudes are in the mind of a racer, all that the racer needs to have in addition include courage, patience and high motivation. If he continues to have these values in himself, if he's in a business or anything that he plan to do, InsyaAllah (with Allah's willing), he will be able to succeed." - Interviewee 3 .

"We go races to get sponsors or just to promote our business only. By we will consider the level of events". Interviewee 1.

"Stop racing? We will know when we should stop getting involved in races. We will know how far we can go. Then, we will decide when to stop. Motorsports is a big thing". Interviewee 1.

"To involve in races is our hobby nowadays. If we don't try out the bikes in our outlet, how can we sell it? A way to market bikes from our shop. If we don't have this advantage, who is going to believe us?" "I am 31 years old. I own this workshop. I took part in races since 1999, right after I finished my secondary school. Then, I worked in other workshop previously. Some at the national and Asia levels". - Interviewee 2.

"Thank you to Allah (God)...since 2006 until 2009. In fact, you still can find me on tracks actively. I learned a lot, seen much...saw opportunities in this sport. This industry is expanding. I am still active in races this year". Interviewee 3.

"For me, we can do business in everything. For example, if someone has talent in playing football, he should be able to provide coaching for others. It is the same for other type of sports. But in motorsports, it is related to business related motorsports. For instance, if a team gets involve in sponsorship program, it is related to business too due to financial budget....be able to increase the team's fund." Interviewee 3.

Referring to the interviewee's reaction, their involvement in business might be based on their experiences only; without attending any specific formal courses on how to conduct a business and to manage it. It is more about survival instead of conscious thoughts on expanding it. In fact, they had high expectations on external funds or investments incorporation to move forward. To summarize the above responses, there is need to have right attitudes and personal qualities in order to change direction from motorsports to business. The interviewees are still involved in races due to passion and to bring out the businesses names in the arena. Although they are active racers, they might consider levels of events and type of bikes used in competitions due to different requirements and different fees they have to pay to the race events' organizers.

\section{Business Networks}

"I was exposed to motorsports business from 1996 until 2005. I started to know dealers that supported races by giving their stuff to racers like me. I got to get close with a dealer from Cheras, Selangor. He offered me a job after I stopped as a full time racer. My work was on sales, to promote products. I worked with that dealer for five years. Then, had a thought to try it myself, started to pen my own business. This business is here since 2005 till now. Thank you, Allah. I'm still with my business. I'm still thinking on expanding it. Currently, I'm a panel for Malaysian Post, CIMB Bank". - Interviewee 1.

"In order to stay in business, having mechanical expertise is not enough. Can't go any further if do not plan to complement it with knowledge on marketing and management. In fact, I'm taking my chances to learn more about it too". - Interviewee 1 .

"Usually, the racer will open a business that is related to motorsports after their glory time because I know this area better". - Interviewee 2 .

"Like I've said before, whenever we get involve in motorsports, we tend to own a business related to motorsports. There are more opportunities there...with my experiences in bikes services or adjusting it or finding new and young talents could be best business opportunities. In management...could be adapted in my own business". Interviewee 3.

The interviewees were exposed to business at early age although in race events. A large amount of time spent by participated in events play roles in shaping their business mindset by mingling around and extending networks among racers, business owners as well as investors. They managed to make full use of their networks among racers and sponsors in order to get advices and projects in business.

\section{Recruitment, Selection and Knowledge Transfer}

"In post career, some of us will only focus on the mechanical by being a team technician or engineer. Some of the racers will race almost their entire youth, and be a part of racers' management team; including own team. Like a mentor to young racers". - Interviewee 1 .

"For me as a racer and most of racers or anyone who got involve in Malaysian motorsports arena... what I observed about the mindset of most racers after they quit the sport, will be to go into business such as in food and beverages like Abdul Rahim Sidek, a national racer. His elder brother too...This shows that racers do not have to go into businesses that are related to motorsports only. But, majority got involved in business related to motorsports when they stopped racing. If they have certificates or degrees they will...they involve with motorsports since they were young. Some have been participating in the sport since they left secondary school hence they have acquired experiences in that area. Therefore, they are still work closely with motorsports after they retire." - Interviewee 3.

"Like I've said before, whenever we get involve in motorsports, we tend to own a business related to motorsports. There are more opportunities there...with my experiences in bikes services or adjusting it or finding new and young talents could be best business opportunities. In management...could be adapted in my own business". Interviewee 3.

Recruitment and selection for new and young talents based on individual effort; senior racers' effort particularly. Experience has shown that that a team requires a balance of 
young and experienced players. By being a mentor, direct knowledge transfer occurs because of their know-how in that respective sport.

\section{E. Customer and Business Impact}

"It is good if riders are involved in this type of business. Customers will trust us more because of our names and experiences. That trust will give us more advantages than others that do not have the same track records". Interviewee 1 .

"We give the best advice if they come to inquire about their bikes". - Interviewee 1 .

His reputation as an excellent racer has impacts on his business particularly concerning customer relationship. $\mathrm{He}$ is able to clearly explain how a bike will perform in relation to the rider's appearance such as size and weight as well as the details of suitable bike drawing from his own knowledge and skills in past events.

\section{F. Collaboration with Local Universities}

"At the moment...there is no potential collaboration because we do not have the right contact. Usually, we depend on ourselves and experiences only." - Interviewee 3

There is a need for significant collaboration with local universities to achieve individual and national agenda in sports. But, there are rooms for mismatch of expectations as a result of constraints on finances plus the limitation of company's size. They realized that volume of sales in the business influence the degree of expertise participation from local universities.

As the prior responses clearly illustrate, business owners possess a number of core qualities, but in different measures. Some issues that came to light are pointed out including the influence of talent development, managing and benchmarking its capabilities at the organizational as well as at the national level. To summarize, the common features as shown in the findings include the followings.

- Ambiguous career path from early involvement until post career as a racer.

- Limited individual visions, passion and qualities that is not enough to promise sustainability of a racer from track to business.

- Business networks promised different expectations as well as perceptions among participants.

- Recruitment, selection and knowledge transfer involve talents versus experiences.

- Customer and business impact; race results been measured for individual and team performance; in business figures in sales been measured for the same reasons too.

- Low collaboration with local universities either for business, management and technical aspects.

Therefore, there is need to increase motorsports events with increasing research efforts as the challenges of benchmarking are quite diverse, complex, and unsettling (Hong et al. 2012).

\section{CONCLUSION}

The scope of opportunities in motorsports is massive. While many businesses start with human resource, customer relationship management, supply chain and finance, the reality is that it is possible for an organization to be embarked from the success in other areas. Thus, the business owners' role will be to act as catalyst to enhance the output from bikes production. They could also support the research and development activities to produce good bikes with good features in term of performance and durability. On the basis of the authors' understanding of the progressively multifaceted activities of this industry in conjunction with other potential significant findings from this study, much attention needs to be focused on the opportunities of this sport. More so, some issues demand immediate actions from Malaysia Youth and Sports Ministry, independent organizations such as Motorsports Association of Malaysia (MAM), Automobile Association of Malaysia (AAM) and Sepang International Circuit (SIC); which will influence policy making and practices inside the track. The scope of this research interest might help to set the boundaries for forthcoming studies. The study is based on interviews with a small sample of active riders. In order to develop the research further, a more extensive sample is required.

\section{ACKNOWLEDGEMENTS}

The authors would like to thank Universiti Malaysia Kelantan and Universiti Sains Islam Malaysia for the opportunity to carry out this research as well as the business owners cum racers who participated in this study.

\section{REFERENCES}

[1] A. E. M. Hesham, "Understanding benchmarking in Egyptian organizations: An empirical analysis," Benchmarking: An International Journal, vol. 15, no. 6, pp. 742-764, 2008.

[2] J. W. Alstete, "Measurement benchmarks or "real" benchmarking? An examination of current perspectives," Benchmarking: An International Journal, vol. 15, no. 2, pp. 178-186, 2008.

[3] L. C. R. Carpinetti and A. M. de Melo, "What to benchmark? A systematic approach and cases," Benchmarking: An International Journal, vol. 9, no. 3, pp. 244-255, 2002.

[4] M. Zairi, "Benchmarking: The best tool for measuring competitiveness," Benchmarking for Quality Management \& Technology, vol. 1, no. 1, pp. 11-24, 1994.

[5] R. B. McKay and E. Chung, "Benchmarking for entrepreneurial survival: Pursuing a cohesive and imperfectly imitable culture," Benchmarking: An International Journal, vol. 12, no. 3, pp. 207-218, 2005.

[6] P. Hong, W. H. Soon, R. J. Jungbae, and P. Kihyun, "Evolving benchmarking practices: A review for research perspectives," Benchmarking: An International Journal, vol. 19, no. 4/5, pp. 444 462, 2012.

[7] J. Sarkis, "Benchmarking for agility," Benchmarking: An International Journal, vol. 8, no. 2, pp. 88-107, 2001.

[8] T. Fernandez, I. P. McCarthy, and T. Rakotobe-Joel, "An evolutionary approach to benchmarking," Benchmarking: An International Journal, vol. 8, no. 4, pp. 281-305, 2001.

[9] S. Rothenberg, B. Schenk, and J. Maxwell, "Lessons from benchmarking environmental performance at automobile assembly plants," Benchmarking: An International Journal, vol. 12, no. 1, pp. 5-15, 2005.

[10] W. K. Chung, "Benchmarking Singapore's high-TQM maturity organizations," Benchmarking: An International Journal, vol. 8, no. 1, no. 8-34, 2001.

[11] C. Cassell, S. Nadin, and M. O. Gray, "The use and effectiveness of benchmarking in SMEs," Benchmarking: An International Journal, vol. 8, no. 3, pp. 212-222, 2001.

[12] P. L. Yean, S. Zailani, and L. S. Keng, "Understanding factors for benchmarking adoption: New evidence from Malaysia," Benchmarking: An International Journal, vol. 13, no. 5, pp. 548-565, 2006.

[13] C. Tansley, "What do we mean by the term "talent" in talent management?" Industrial and Commercial Training, vol. 43, no. 5, pp. 266-274, 2011. 
[14] C. Ashton and L. Morton, "Managing talent for competitive advantage: Taking a systemic approach to talent management," Strategic HR Review, vol. 4, no. 5, pp. 28-31, 2005.

[15] M. Powell and G. Lubitsh, "Courage in the face of extraordinary talent: Why talent management has become a leadership issue," Strategic HR Review, vol. 6, no. 5, pp. 24-27, 2007.

[16] M. Buckingham and R. M. Vosburgh, "The 21st century human resources function: It's the talent, stupid!” Human Resource Planning vol. 24 , no. 4 , pp. 17-23, 2001.

[17] S. M. Dahlgaard-Park, "Decoding the code of excellence-for achieving sustainable excellence," International Journal of Quality and Service Sciences, vol. 1, no. 1, pp. 5-28, 2009.

[18] R. Stuart-Kotze and C. Dunn, How to Find, Measure and Manage Your Top Talent, Britain: Prentice Hall, 2008.

[19] J. P. Ingham and Strategic Dynamics, "Closing the talent management gap. Harnessing your employees 'talent to deliver optimum business performance," Strategic HR Review, vol. 5, no. 3, pp. 20-23, 2006.

[20] C. Farley, "HR's role in talent management and driving business results," Employment Relations Today, John Wiley \& Sons, Inc., pp. 55-61, 2005.

[21] T. P. Stank, J. P. Dittmann, and C. W. Autry, "The new supply chain agenda: A synopsis and directions for future research," International Journal of Physical Distribution \& Logistics Management, vol. 41, no. 10, pp. 940-955, 2011.

[22] J. Liu, A. Shrivastava, and S. W. Ho, "Transference of skills between sports and business," Journal of European Industrial Training, vol. 22, no. 3, pp. 93-112, 1998.

[23] B. Burnes and H. O'Donnell, "What can business leaders learn from sport?" Sport, Business and Management: An International Journal, vol. 1, no. 1, pp. 12-27, 2011.

[24] J. Liu, A. Shrivastava, and S. W. Ho, "Transference of skills between sports and business," Journal of European Industrial Training, vol. 22, no. 3, pp. 93-112, 1998.

[25] M. Joshi, A. Srivastava, and V. A. Aggarwal, "Sporting family business generations," Journal of Chinese Entrepreneurship, vol. 5, no. 2, pp. 173-192, 2013.

[26] C. Ashton and L. Morton, "Managing talent for competitive advantage: Taking a systemic approach to talent management," Strategic HR Review, vol. 4, no. 5, pp. 28-31, 2005.

[27] J. K. Eskildsen and M. L. Nussler, "The managerial drivers of employee satisfaction and loyalty," Total Quality Management, vol. 11 , no. 4, pp. 581-588, 2000

[28] A. Weyland, "Engagement and talent management of Gen Y.," Industrial and Commercial Training, vol. 43, no. 7, pp. 439-445, 2011.

[29] C. Tansley, "What do we mean by the term "talent" in talent management?" Industrial and Commercial Training, vol. 43, no. 5, pp 266-274, 2011.

[30] C. M. Harris, G. C. MacMahan, and P. M. Wright, "Talent and time together: The impact of human capital and overlapping tenure on unit performance," Personnel Review, vol. 41, no. 4, pp. 408-427, 2012.

[31] R. McNutt and P. C. Wright, "Coaching your employees: Applying sports analogies to business," Executive Development, vol. 8, no. 1, pp. 27-32, 1995.

[32] V. De Bosscher, P. De Knop, M. van Bottenburg, S. Shibli, and J. Bingham, A Global Sporting Arms Race: An International Comparison of the Elite Sport Policies and Climate in Six Nations, Denmark, Aarhus, June 4th 2008.

[33] G. A. Churchill Jr, Marketing Research: Methodological Foundations, $7^{\text {th }}$ ed. Dryden Press: Fort Worth, 1999.
[34] J. Ritchie, J. Lewis, and G. Elam, "Designing and Selecting Samples," Qualitative Research Practice: A Guide for Social Science Students and Researchers, 2003, pp. 77-108.

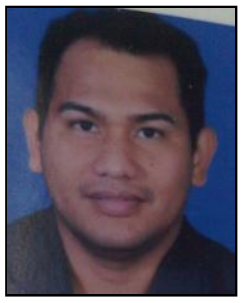

Syarizal Abdul Rahim is a lecturer in Universiti Malaysia Kelantan, Malaysia. He was born in Mentakab, Pahang in June, 1976. He obtained his first degree in accounting from Universiti Teknologi MARA (UiTM) in 1999. He completed the master degree in business administration from Universiti Utara Malaysia (UUM) in 2009.

From 2002 to 2005, he was employed by Royal Bank of Scotland in Aberdeen. Then, he decided to change his direction by worked for Standard Chartered Bank in Singapore for four years. Before he joined the academics, he attached with Bank Muamalat Malaysia Berhad. He is a member automobile association of Malaysia (AAM) due to high involvement in motorsports. His research interests are business and management particularly in motorsports.

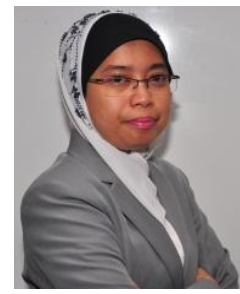

Norailis Ab. Wahab is a senior lecturer in the Faculty of Economics and Muamalat, Universiti Sains Islam Malaysia. She is a member of Malaysian Muamalat Association (MMA) and the Malaysian consumer and family economics association (MACFEA). She was born on September 4, 1978 in Negeri Sembilan, Malaysia. She attained her first degree in industrial economics in 2000 and the master degree in science (productivity and quality enhancement) in the following year from Universiti Kebangsaan Malaysia. In the middle of 2009, she had been awarded PhD from the University of Stirling, Scotland.

She joined SME Corporation Malaysia for three months in 2012 through USIM Academic Staff Attachment Program to gain industrial experiences and strengthen the networking with practitioners in small and medium enterprises (SMEs). This year, she has published two case studies on umrah management and organizational issues in "Integrated Muamalat Case Study" published by the PENERBIT Universiti Sains Islam Malaysia. She is actively involves in research on benchmarking, supply chain and umrah management.

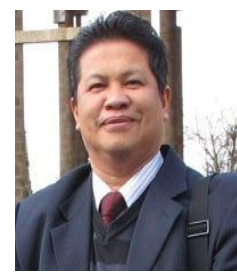

Razli Che Razak is currently a registrar at University Malaysia Kelantan. He is a professor in operations management and quantitative techniques of Faculty of Entrepreneurship and Business Universiti Malaysia Kelantan. He was born in November 1963 in Tumpat, Kelantan, Malaysia. He attained his master degree of science in operational research at the Department of Management Science, Strathclyde Business School University of Strathclyde, United Kingdom in 1988 and bachelor degree of economics (economic statistics), from Universiti Kebangsaan Malaysia, Malaysia in 1986. His expertise is mainly in operational management. In 2001, he had been awarded $\mathrm{PhD}$ degree from University Sains Malaysia.

$\mathrm{He}$ is a member of Management Science and Operations Research Society of Malaysia (MSORSM). 